\title{
The Role of History In Informality In The Global South City Of Kuala Lumpur: The Case Of Kampong Bharu Development
}

\author{
Luiza Farnese L. Sarayed-Din¹, Rosilawati Zainol2*, Faizah Ahmad ${ }^{3}$ \\ ${ }^{1}$ Department of Urban and Regional Planning, Faculty of Built Environment, University of Malaya, 50603 \\ Kuala Lumpur, Malaysia.
}

${ }^{2}$ Sustainable Planning and Development Unit, Centre for Sustainable Urban Planning and Real Estate (SUPRE), Faculty of Built Environment, University of Malaya, 50603 Kuala Lumpur, Malaysia.

${ }^{3}$ Malaysian Institute of Planners, 47301 Petaling Jaya, Selangor, Malaysia

Email: luiza.sarayed@gmail.com, rosilawatizai@um.edu.my, faizah2108@yahoo.com.au

\begin{abstract}
This study explores history as a critical element associated with informality in the global south city of Kuala Lumpur. Framed by such critical element and embedded in a social constructivism approach it investigates a historical inhabited urban area under the pressure of development located in the heart of Kuala Lumpur: Kampong Bharu. Making use of secondary data review, preliminary field visit, ten semi-structured interviews and observation from June 2012 to June 2015, this study first presents the urban development history of Kampong Bharu. Following that, it then discusses Kampong Bharu development in light of two emergent themes identified throughout the findings of this research, namely the modernist urban practices and single accounts of history. Highlighting how the understanding of informality is historically shaped by the same planning interventions that were supposed to 'fix it', this study explores the implication of those two emergent themes on the very production of global south cities' urban crisis, broadening the understanding of challenges and opportunities for development in Kuala Lumpur.
\end{abstract}

Keywords: Kuala Lumpur, Kampong Bharu, Informality, Development, Global South, History

\section{INTRODUCTION}

The beginning of the $21^{\text {st }}$ century marked a major shift in the urbanization of the world, with the majority of the human population living in cities, particularly cities of the global south (UN-HABITAT, 2006). These massive economic and demographic shifts have revealed the inadequacy of the current planning practices in efficiently addressing global south cities' core challenges. Prioritizing ideas that come from the Anglophone cities forged by

\footnotetext{
${ }^{1} \mathrm{PhD}$ candidate at the Faculty of Built Environment, University of Malaya Email: luiza.sarayed@gmail.com

2 Senior lecturer at the Department of Urban and Regional Planning and Head of Sustainable Planning and Development and Unit Head, Centre for Sustainable Urban Planning and Real Estate, Faculty of Built Environment, University of Malaya. Email: rosilawatizai@um.edu.my

* corresponding author

3 Registered Town Planner and MIP Education Committee Member. Email: faizah2108@yahoo.com.au
} 
the Industrial Revolution, these existing urban practices have the 'tendency to overlook the rapidly growing cities where traditional authority, religious identity or informality are as central to legitimate urban narratives as the vacillations in modern urban capitalism public policy' (Parnell \& Oldfield, 2014: 2). At the outset, these major shifts have shown the urgency to study informality in the context of the global south, especially about the planning practices.

Molded by the complex mixture of colonial background, rapid urban growth and dubious modernist planning practices, the city of Kuala Lumpur, Malaysia is considered an insightful example of a global south city. Going through a sequence of urban development transformations since the 1990s, one of the biggest challenges that planning practices have posed to Kuala Lumpur, more specifically in the emblematic area of Kampong Bharu located in the heart of the city, highlights the urge of an urban practice compromised with different ways of looking at informality. Aiming to address such challenge, this case study research paper investigates this historical inhabited urban area's development history highlighting how the understanding of informality is historically shaped by the same planning interventions that were supposed to 'fix it'. Framed by one of the critical elements of informality indicated by the southern urbanism, namely history (Hammami, 2012; Holston, 1989, 2008, 2009; Jacobs, 1992; Miraftab, 2009; Robinson, 2006; Sandercock, 2003; Watson, 2009), this study sheds light on the role of modernist planning and single accounts of history in shaping what is considered informality in such urban settings.

Based on the analysis of official documents and three years of observation and application of semi-structured interviews with key stakeholders, this paper firstly presents the urban development history of Kampong Bharu, focusing on the current Kampong Bharu Master Plan, and then discusses it in light of two emergent themes associated with history in informality, namely modernist's urban practices and single accounts of history. Fleshing out the importance of looking at informality in a fractal fashion, this study discusses the sharp influence of such urban practices and historical accounts in the production and understanding of informality in Kuala Lumpur and, consequently, in other global south cities.

For the purpose of this study, the term 'global south' refers to a broader and non-hierarchical frame of view that acknowledges the common 'colonial past and more recent shared development history' (Miraftab \& Kudva, 2014: 4) of certain cities.

\section{LITERATURE REVIEW}

\subsection{History As A Critical Element Of Informality}

Focusing on experiences of cities everywhere, but in particular those of the global south, some scholars have broadened the understanding of informality. Moving away from the idea of poverty as something that should be 'fixed' by urban development practices, authors such as Roy (2009); Simone (2004); Watson (2009); Yiftachel (2009) have examined the Western/conventional urban planning approaches and advanced in new ways of addressing the 'increasing gap between current approaches and growing problems of poverty, informality, ... particularly [but not only] in cities of the global south' (Watson, 2009: 2259). Casting a critical eye towards such challenges, these authors make use of themes such as power, history and people's relation to broadening the understanding of informality. Overall, informality is seen by them as a structural planning feature historically conducted by State power and intertwined by both market forces and survival efforts of the marginalized, concept that this study agrees with. Conscious of the complexity of each of those critical elements, this paper focuses on one of them: the history as a critical element of informality. 
In order to critically assess how the idea of informality is shaped by the planning history of such places, as well as understand whose history is being uncovered and by whom, one should consider the different voices and interlayered processes that constitute the history and the past in one place. About that, David Harvey (2000: 3) argues that 'knowledge of the past should be seen as a political resource, and that the control and interpretation of a particular version of the past are related to power differentiation and the legitimization of authority'. Delving into Harvey's thoughts, Hammami (2012:16) also argues that the consideration of history as a single movement or personal project often indicates a particular version of the past and defends that 'collective memories are constructed in relation to the way the past is understood and negotiated'. In addition to that, Miraftab (2009) historicize the notion of citizenship and defends the decolonization of planners' imagination proposing an upsidedown look in the world of development. In doing so, he suggests that a conscious planning exercise should address questions such as whose history? and critically assess the underlying assumption that associates deep informality in global south cities with failure. Instead, he argues, informality could be seen as a 'triumphant sign of their success in resisting the Western models of planning and urban development' (Miraftab, 2009: 45).

Taking the urban pasteurization promoted by the modernist city discourse throughout the $20^{\text {th }}$ century as an example, the existence of one widely accepted story of planning history reinforced certain urban practices as correct and expected, while others are not welcome. For instance, the $19^{\text {th }}$ century understanding of urban problems as a disease of the social body, 'provided the urban reformers justifications for the 'Haussmannization' of cities throughout Europe and Americas' (Holston, 2009: 248). Another example is the planning legislation of some countries in Africa and cities in India that are still based on the previous colonies' laws, namely British and/or European. About that, Watson (2009: 2262) highlights that 'in much of the global south, master planning, zoning and visions of urban modernism are still the norm'.

Having such examples in mind, one should agree that a democratic dialogue among cities everywhere demands both a critical eye towards the 'taken for granted' urban history of each place and an investigative attention to grassroots and often neglected urban experiences. Taking history as one of the critical elements to deeply understanding cities and then imagining their future differently, Leonie Sandercock (2003: 45) affirms that the planning exercise needs to take into consideration those different accounts of the past. To do that, she suggests, planners should draw their attention to 'some of the glaring absences in mainstream accounts of history' and make an effort to give voice to different experiences.

Based on that one would agree that the planning exercise, comprised with looking at an urban community and searching for histories other than the official, represents a paradigm shift. Using the James Holston (2008; 2009)'s term insurgent, Sandercock (2003) highlights the existence of alternative traditions of planning that are different from those practised by the state. James Holston (2009:246) has created the concept of insurgent citizenship to express the alternative formulations of citizenship that take place once the 'marginalized citizens and noncitizens' contest their exclusion within their everyday life. Sandercock (2003), in turn, has smartly used the expression 'insurgent' to qualify planning histories different from those of the state, emphasizing the multiple and revolutionary characteristics of such different accounts of the past.

As an example, both Sandercock $(2003)$ and Holston $(2008,2009)$ have pointed out how the $19^{\text {th }}$ century urban single historical and geographical focus plays a pivotal role in what is accepted as the righteous city image. What is more, Sandercock (2003) has described the planning history of certain invisible minorities within urban settings, such as women, the black population and different religious groups shedding light on the hidden meanings of certain planning practices, such as urban redevelopment, etc.

All in all, delving into the previous discussion, this study agrees about the impacts of history into what is regarded as informal in global south urban settings. To undertake such critical analyses, the planning exercise should be 
then committed to multiple histories of urban communities providing 'a foundation for an emerging alternative [to the modernist] paradigm for planning in multicultural cities' (Sandercock, 2003: 38).

\section{METHODOLOGY}

Given the nature of the problem, which is intertwined with people's relations, issues of power and impact of history, and being coherent with a social constructivist approach and qualitative methodology, this work follows the case study strategy of inquiry. This study's methodological flow is depicted in Figure 1 that highlights the interconnection between the main outputs of the literature review, data collection and findings and discussion.

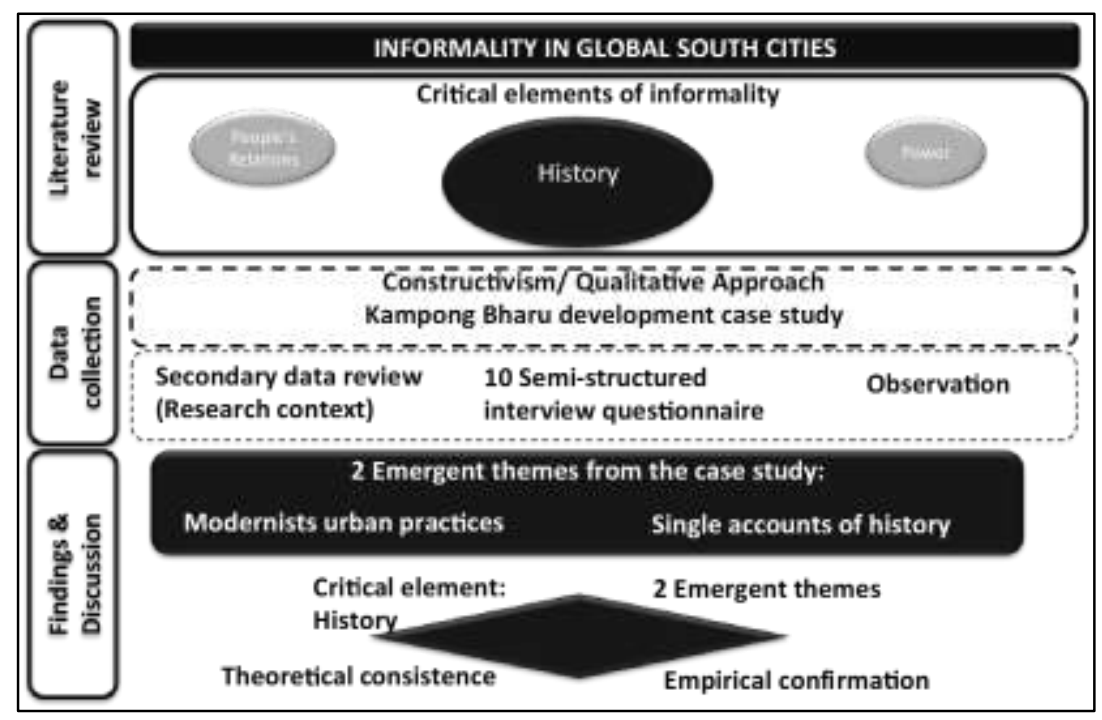

Figure 1: Research flow

An extensive desk study gathering historical, official/governmental, media and technical data and ten in-depth interviews followed by observation have been used. These interviews and observation have been initially delineated by the reviewed literature and then followed a snowballing sampling strategy. What is more, the collected data is analyzed and interpreted following the social constructivist-interpretative approach and makes use of analytical tools, such as the Computer Aided Qualitative Data Analyses Software - CAQDAS - NVivo ${ }^{\mathrm{TM}}$.

The theoretical perspective under which the data is interpreted has been extracted from the critical literature related with informality in global south cities - particularly focusing on history as a critical element - explained in the previous section. Then, as a result of the analytical process, which explored history as a critical element of informality, this study identified two emergent themes. Hence, the critical element History [from Literature review] and two emergent themes [from Findings and analyses] conducted the flow of this study discussion through cross-referencing the empirical confirmations found throughout the analytical process with both the theories reviewed as well as the Kampong Bharu's research context - this later, presented in the following section.

\section{RESEARCH CONTEXT}

\subsection{Kampong Bharu Urban Development}


Kuala Lumpur's traditional urban village Kampong Bharu was set up as a Malay Agricultural Settlement [MAS] (Smith \& Bender) in 1899, when the Malay states were under British rule. Strongly marked by its history and continuous state-led urban interventions within and surrounding Kampong Bharu, this urban village represents a complex terrain. For instance, Kampong Bharu's almost insoluble land issue has its origin once the MAS had been created. The allowance to live in that region was ethnically guided - only Malays - and, in the Federation of Malaya Government Gazette of 1951, the description of what it meant by 'Malay' was registered. A Malay, the document says, is who belongs to 'any Malay race who habitually speaks the Malay language, professes the Muslim religion and practices Malay customs and a person approved by the board as Malay’ (Selangor, 1951: 18).

After independence in 1957 and following the New Economic Policy (NEP) era, the Kuala Lumpur City Centre became the most strategic area of government investment. From that time onwards, Kampong Bharu has remained the bastion of a Malay Kuala Lumpur and has, at the same time, been under the pressure of the 'new modern Malaysia' symbolized by shopping, business skyscrapers and high-end condominiums. After so many modernizing interventions surrounding Kampong Bharu, the settlement '... stands as a symbol of past oppressions, of Malay economic stagnation, of radical responses in a generally docile community and of economic opportunities lost or stolen by misguided law' (King, 2008: 38).

On top of that, Bunnell (2002) suggests that the very existence of a kampong within the heart of a would-be worldclass city and nation reveals the urban limits of such authoritative urban practices. Explaining the history and investigating the values underneath the rise of such new urban "Malayness" discourse, in which " modern" and “clean" city landscapes have been inherited as a barometer for the progress of Malaysia' Bunnell (2004: 302), highlights that the term 'kampong' is usually associated with urbanization failure and something undesirable.

It is important to highlight that since the 1984 Kuala Lumpur Structure Plan - KLSP there were different government efforts in 'solving' the Kampong Bharu issue. In the 1984 KLSP, for instance, there is a whole section dedicated to Malay Reservation and, more specifically, to Kampong Bharu. Stating that the major problems of Malay Reservations' low path in changing 'from the basically rural settlement and activities to the modern urban norms' stems from legal to socio-psychological constraints, the Kuala Lumpur City Hall (1984: 175) underscores that Kampong Bharu is expected to be the locus for fostering 'Bumiputera's presence in the Federal territory urban economy'.

However, it was during the 1990s that Kampong Bharu witnessed the biggest 'modernization' pressure. Embedded in the Vision 2020 principles, major developments in Kuala Lumpur City Centre have demolished the bridge connecting Kampong Bharu and the city center and built a wall contiguous to the newly constructed AmpangKuala Lumpur Elevated Highway [AKLEH], the first elevated highway in Malaysia in 1996. Another example is the construction of Kampong Bharu subway station in 1999 also next to this wall. All in all, most of the urban interventions and megaprojects associated with Kuala Lumpur City Centre development throughout the 1990s had an immense impact on Kampong Bharu everyday life.

Produced as part of the Kuala Lumpur City Plan 2020 (Kuala Lumpur City Hall, 2006), Kampong Bharu received a new Development Plan in 2008. With a strong focus on real estate development in and around Kampong Bharu, the plan presents four potential development scenarios for Kampong Bharu. Increasing the level of interventions and real estate development, the scenarios were: $1^{\text {st }}$ 'Following the trend', $2^{\text {nd }}$ 'Developing selected lands', $3^{\text {rd }}$ 'Re-integrating the area to the surroundings', $4^{\text {th }}$ 'Comprehensive development'. Besides that, a detailed set of development proposals for each area of Kampong Bharu and a potential governance structure and estimated costs were presented. The suggestions stemmed from the development of Auto-City mall to the design of a backup water supply system for the region (Kuala Lumpur City Hall, 2008). 


\subsection{Development Master Plan of Kampong Bharu 2014}

In 2014, however, a further step was made towards Kampong Bharu redevelopment. Following some of the general guidelines of the 1984 and 2003 KLSP [Kuala Lumpur Structure Plan] and Kampong Bharu Development Plan 2008 governance indications, the Kampong Bharu Development Corporation (PKB (Perbadanan Pembangunan Kampong Bharu, in Bahasa Melayu) was officially formed in 2011 (Parlimen Malaysia, 2011). Based on the fourth scenario of the 2008 Kampong Bharu plan, the one contemplating major changes and intervention, the PKB launched the Comprehensive Development Master Plan of Kampong Bharu in 2014. With a strategically powerful message, the mission and vision of this master plan highlight both the Malay culture and economic boost of Kampong Bharu, as well as the importance of landowners not to be 'left behind in the future development path' (PPKB, 2014: 1.2, author's translation).

Based on Kampong Bharu Development's first two objectives stated in both Kuala Lumpur City Plan 2020 (2006) as well as Kampong Bharu Master Plan (2014: 29), this urban intervention should enhance growth by 'encouraging innovative solutions in planning land development and redeveloping areas with catalyst activities'. Overall, within the package of innovative solutions PPKB (2014) included in the intensive mixed-use development, based on vertical growth, increasing the density of residents from 18,372 to 70,000 (PPKB, 2014: 33) and attracting a variety of businesses to enhance the value and usage of the land. Further, as highlighted on the PPKB (2015) website, to make Kampong Bharu a profitable business area, the development focuses on strengthening trade and financial activities towards international trade and knowledge base.

From the perspectives of the new population density and business space, Kampong Bharu Master Plan expects that by 2035 both more optimal business spaces (from 123,539 sq. feet to 53,336,130 sq. feet in 2035 (PPKB, 2014: 34)) as well as 17,500 housing units of various sizes and levels of capability are going to be available for a new and diverse population of Kampong Bharu. The vertical growth is boosted by the recent increase of the Kampong Bharu plot ratio from 1:6 to 1:10. While for the redevelopment of catalyst actions, PPKB (2014) suggests the upgrade of existing economic practices as well as the implementation of new catalyst activities to attract other businesses and people to the area. In the Master Plan, six categories are identified as catalysts: the traditional food and commerce, education, travel and tourism, car, fashion, and medical (PPKB, 2014: 29). In addition to that, nine other general activities, such as the construction of hotels and serviced apartments, are indicated as catalysts to be implemented throughout the development intervention in order to attract people and investment to the area.

All in all, seen always as an issue and a place to be 'modernized', from the first attempt in 1985, followed by the comprehensive Kampong Bharu Development Plan in 2008 and currently the Kampong Bharu Master Plan launched in 2014, Kampong Bharu has always been a conflicting arena of political and economic discussion, legal lacunas, and ethnical and religious affirmation.

\section{FINDINGS AND DISCUSSION}

\subsection{History And Informality In Kampong Bharu Development}

Drawing on Holston (1989, 2008, 2009); Jacobs (1992); Robinson (2006); Sandercock (2003); Watson (2009) Miraftab (2009); Hammami (2012)'s understanding of history as a critical element of informality this section discusses the findings from the case of Kampong Bharu development. This discussion examines how, in this instance, both the traditional planning embedded in development practices as well as the ethnical and/or religious groups' invisibility through the dominance of another collectively accepted history impacts the idea of informality 
in the global south city of Kuala Lumpur. To that end, the following two subsections respectively explore the two emergent themes associated with history, namely modernists' urban practices and single accounts of history. Further, reflecting on empirical confirmations from the case study, each of these themes is explored through examples such as the gentrification process; the 'catching up' mechanisms; the utilization of zoning, Master Plan and other controlling instruments ruling what is the 'formal modern city'; struggles over space and place and questions of belonging, identity and acceptance of difference. The cross-referencing table 1 depicts and summarizes the discussion process undertaken throughout this section, highlighting the emergent themes, empirical confirmation and conceptual consistency of the critical element of informality explored in this study, namely history.

Table 1: Cross-referencing discussion table.

\begin{tabular}{|l|l|l|l|}
\hline $\begin{array}{c}\text { Critical Elements } \\
\text { of Informality } \\
\text { [Literature Review] }\end{array}$ & $\begin{array}{l}\text { Emergent Themes } \\
\text { [Findings: } \\
\text { Case Study] }\end{array}$ & \multicolumn{1}{|c|}{$\begin{array}{c}\text { Empirical Confirmation } \\
\text { [Case Study] }\end{array}$} & $\begin{array}{c}\text { Conceptual Consistency } \\
\text { [Literature Review] }\end{array}$ \\
\hline \multirow{3}{*}{ History } & $\begin{array}{l}\text { Modernists urban } \\
\text { practices }\end{array}$ & $\begin{array}{l}\text { - 'Catching up' mechanisms } \\
\text { - Zoning, Master plan and other controlling instruments ruling } \\
\text { what is the 'formal modern city' }\end{array}$ & $\begin{array}{l}\text { Harvey (1989); Holston (1989, } \\
\text { 2008, 2009); Jacobs (1992); } \\
\text { Robinson (2006); Sandercock } \\
\text { (2003); Watson (2009) }\end{array}$ \\
\cline { 2 - 5 } & $\begin{array}{l}\text { Single accounts of } \\
\text { history }\end{array}$ & $\begin{array}{l}\text {-Struggles over space and place: land ownership as an issue. } \\
\text {-Questions of belonging, identity and acceptance of difference }\end{array}$ & $\begin{array}{l}\text { Hammami (2012); Harvey } \\
\text { (1989, 2000); Holston (2008, } \\
\text { 2009); Miraftab (2009); } \\
\text { Sandercock (2003) }\end{array}$ \\
\hline
\end{tabular}

\subsection{Modernists' Urban Practices}

As explored in the Literature Review section, Harvey (1989); Holston (1989, 2008, 2009); Jacobs (1992); Robinson (2006); Sandercock (2003); Watson (2009) have critically indicated how the $19^{\text {th }}$ century urban single historical and geographical focus plays a pivotal role in what is accepted as the righteous city image. Supported by such understanding and based on the research context previously explained and the case study analyses, this study highlights the role of modernists' urban practices throughout history as a producer of informality in Kampong Bharu. A close look at the empirical examples of either the gentrification process or the catching up mindset embedded in the Kampong Bharu Master Plan idea of modernity, or its zoning and other controlling strategies, empirically reinforces the argument that modernist development practices still dominating what is the 'formal modern city' and regarding as informal what does not fit into such framework.

After Malaysia's independence in 1957, Kuala Lumpur witnessed the rise of a future-oriented a historical modernity discourse (Bunnell, 1999, 2002, 2004; Thompson, 2000, 2004) led by development plans. Both the discourse as well as modernist development plans have culminated in the construction of KLCC as the symbol of modern urban Malayness (Bunnell, 1999) and regarded Kampong Bharu as the locus of Malay economic stagnation and un-ruled organization (King, 2008). Delving deeply, once explaining the current Kampong Bharu Master Plan rationale, the interviewees of this study have used words such as slum, poor and informal, to qualify Kampong Bharu, while Kuala Lumpur city center was depicted as modern, clean and developed. It reveals, as explained by Robinson (2006: 11), the catching up a mechanism that modernist practices posed over the cities, particularly in the global south, in which 'imitative urbanism and the regulating fiction of catching up to wealthier, Western cities' is the norm.

Another example of the strong presence of such catching up/copy-cat approach embedded in the development practices of Kampong Bharu case study is the focus on the increase of the plot ratio and zoning as a way of attracting investment and development to the area. This study reveals that Kampong Bharu urban development rationale is based on vertical development, intensive mixed use of the land and requalification of the area through 
a controlling strategy based on zoning and plot ratio strategy. In line with Watson (2009)'s criticisms, this study concludes that the usage of such controlling mechanisms still the norm in the global south and reveals the need for a revitalization of such approaches to release global south cities from the imaginative straightjacket of imitative and regulatory urbanism.

The above findings are in line with what Harvey (1989); Holston (1989); Jacobs (1992); Sandercock (2003) have critically suggested as one of the challenging modernist city issues, which is the deep loss of human fabric as a result of devastating urban renewal and redevelopment practices. Although not explicitly associating such issues of modernist practices with the production of informality itself, these authors (Harvey, 1989; Holston, 1989; Jacobs, 1992; Sandercock, 2003) have criticized the regulative and controlled role of modernist planning and how these practices have raised a strong dichotomy in cities, embracing the idea of modernity that fits a specifical group of people and interests, which, as a consequence, excludes other city's experiences as not welcomed, traditional and 'to be fixed'.

All in all, reinforcing the idea of informality as an issue to be solved, and as something to be formalized, the modernist practices have shown their strong influence in determining what is regarded as accepted and what should be 'fixed' within Kampong Bharu development process. With symbolical landmarks such as the Twin Towers in Kuala Lumpur, Kampong Bharu has been shadowed and trapped by the binary formal-informal discourse embedded in modernist urban practices that framed the idea of modernity and formality in this city.

\subsection{Single Accounts of History}

Kampong Bharu case study also illustrates that the association of history and informality goes beyond the realm of modernists' urban practices and can also be seen when critically analyzing the predominance of a single account of history within Kuala Lumpur urban settings. Such conscious assessment of whose history is privileged as the only version of the past of these areas reveals both how specific ethnical or religious groups are silenced or made invisible through the dominance of another collectively accepted history and the impact of that on this groups struggles over space and recognition.

These findings are in line with Hammami (2012); Harvey (1989, 2000); Holston (2008, 2009); Miraftab (2009); Sandercock (2003)'s claims for a multicultural interpretation and acknowledgment of different versions of the past as a way of addressing issues of informality in global south cities. What is more, such findings have as key empirical confirmations from the case study both the struggles over space and place as well as the questions of belonging, identity and acceptance of difference that take place in both historical inhabited urban areas under the pressure of urban development agendas.

For instance, these challenges are seen in the case of Kampong Bharu development through the complexity of land ownership and its intricate relation with ethnicity. The official criticisms about the multiple ownership as well as Malay status of Kampong Bharu's land as an issue to be solved expose the incapacity of the current historical understanding of the area to comprehend and value indigenous Malay planning practices. Delving deeply into this example, the findings demonstrate that the subliminal association of kampong and Malay lifestyle being something old and in need to be 'modernized' (Bunnell, 2002) fueled the official discourse that diminishes the deep intangible value a land carries in Malay culture.

On the other hand, this intangible value is usually re-described - by government official interviewees - as the Malay's lack of market vision and uses it as a justification for the need to 'open up' the Malay reserve status of Kampong Bharu in order to attract 'heavy weight' investors that would foster the development on the expected modern terms. As highlighted by Sandercock (2003) and Holston (2008, 2009), this attitude that regards as 
undesirable the planning history of a specific group sheds light into the hidden meanings of urban development practices in cities, more specifically in global south cities.

\section{CONCLUSION}

The findings from the study span a broad range of challenges embedded in the development practices of Kampong Bharu. Focusing the discussion on the role of history in the definition of what is informality within this urban setting, this study shows that such definition is affected by the single accounts of history manifested through structural planning approaches, such as the ethnical and social choices embedded in urban upgrading agenda. Furthermore, this study clearly reveals the impact of modernists' urban practices throughout history as a mechanism that legitimizes what is considered formal and modern in this global south city, while leaving aside what is regarded as informal and that should be 'fixed' by the same practices that have helped generate it. In addition to that, this study stresses both how ethnical and religious discourse configures or consents with what is regarded as informal in such historical inhabited urban areas under the pressure of development, as well as the importance of planning to be aware of such alternative formulations of citizenship as a way of emphasizing the multiple and revolutionary characteristics of such different accounts of the past.

Drawing on both, the revealed context of urban pressure that Kampong Bharu is going through and on the two emergent themes - namely modernist's urban practices and single accounts of history - the study have further explored history as a critical element of informality. Moving away from the idea of informality as an issue of poverty, this study explored the implication of those two emergent themes on the very production of global south cities' urban crisis.

\section{REFERENCES}

Azuidah, Yang. (2011). Kampung Bharu, my neighbourhood. Jendela-DBKL, November.

Bunnell, Tim. (1999). Views from above and below: the Petronas Twin Towers and/in contesting visions of development in contemporary Malaysia. Singapore Journal of Tropical Geography, 20(1), 1-23.

Bunnell, Tim. (2002). Kampung Rules: Landscape and the Contested Government of Urban(e) Malayness. Urban Studies, 39(9), 1685-1701.

Bunnell, Tim. (2004). Re-viewing the Entrapment controversy: Megaprojection,(mis) representation and postcolonial performance. GeoJournal, 59(4), 297-305.

Hammami, F. (2012). Heritage in Authority-Making: Appropriating Interventions inThree Socio-Political Contexts. KTH.

Harvey, David. (1989). The postmodern condition: An enquiry into the origins of cultural change: Blackwell, Oxford.

Harvey, David. (2000). Continuity, authority and the place of heritage in the Medieval world. Journal of Historical Geography, 26(1), 47-59.

Holston, James. (1989). The Modernist City: An Anthropological Critique of Brasilia: University of Chicago Press.

Holston, James. (2008). Insurgent citizenship: Disjunctions of democracy and modernity in Brazil: Princeton University Press.

Holston, James. (2009). Insurgent Citizenship in an Era of Global Urban Peripheries. City \& Society, 21(2), 245267. doi: 10.1111/j.1548-744X.2009.01024.x

E-18/300048/84, Tombamento Pedra do Sal (1984).

Jacobs, Jane. (1992). The Death and Life of Great American Cities. New York: Vintage Books Edition, Random House. 
Ju, Seo Ryeung, Omar, Saari, \& Ko, Young Eun. (2012). Modernization of the Vernacular Malay House In Kampong Bharu, Kuala Lumpur. Journal of Asian Architecture and Building Engineering, 11(1), 95102.

King, Ross. (2008). Kuala Lumpur and Putrajaya: negotiating urban space in Malaysia: NUS Press.

Kuala Lumpur City Hall. (1984). Kuala Lumpur Structure Plan. Kuala Lumpur.

Kuala Lumpur City Hall. (2006). Draft Kuala Lumpur City Plan 2020.

Kuala Lumpur City Hall. (2008). Draft Pelan Bandar Raya Kuala Lumpur 2020 Jilid 4: Kampong Bharu. Kuala Lumpur: DBKL.

Miraftab, Faranak. (2009). Insurgent planning: situating radical planning in the global south. Planning Theory, $8(1), 32-50$.

Miraftab, Faranak, \& Kudva, Neema. (2014). Cities of the global South reader: Routledge.

Akta 733 Perbadanan Pembangunan Kampong Bharu (2011).

Parnell, Susan, \& Oldfield, Sophie. (2014). The Routledge handbook on cities of the global south: Routledge.

PPKB, Perbadanan Pembangunan Kampong Bharu. (2014). Pelan Induk Terperinci Pembangunan Kampong Bharu-PITPKB. Kuala Lumpur.

PPKB, Perbadanan Pembangunan Kampong Bharu. (2015). http://www.pkb.gov.my. Retrieved Aug, 2015,2015 Robinson, Jennifer. (2006). Ordinary Cities: between modernity and development. USA and Canada: Routledge. Roy, Ananya. (2009). Why India Cannot Plan Its Cities: Informality, Insurgence and the Idiom of Urbanization. Planning Theory, 8(1), 76-87. doi: 10.1177/1473095208099299

Sandercock, Leonie. (2003). Cosmopolis II: Mongrel Cities of the 21st Century. London \& New York: Continuum.

Selangor, Government of. (1951). Federation of Malaya Government Gazette. Kuala Lumpur.

Simone, AbdouMaliq. (2004). For the city yet to come: Changing African life in four cities: Duke University Press.

Smith, Michael P, \& Bender, Thomas. (2001). City and nation: rethinking place and identity (Vol. 7): Transaction Pub.

Teng, Yip Yoke. (2014, 24 January). After more than a century, Kampung Baru remains very much a kampung, The Star Online.

Thompson, Eric C. (2000). In KL-and-Kampung: Urbanism in Rural Malaysia. University of Washington.

Thompson, Eric C. (2004). Rural villages as socially urban spaces in Malaysia. Urban Studies, 41(12), 23572376.

UN-HABITAT. (2006). State of the World's Cities Report 2006/2007: United Nations Human Settlements Programme (UN-HABITAT).

Watson, Vanessa. (2009). Seeing from the South: Refocusing urban planning on the globe's central urban issues. Urban Studies, 46(11), 2259-2275.

Yiftachel, Oren. (2009). Theoretical Notes On 'Gray Cities': the Coming of Urban Apartheid? Planning Theory, 8(1), 88-100. doi: 10.1177/1473095208099300 